\title{
SIGNIFICANT INSIGNIFICANCES: WINSTON SMITH'S DIARY AND OTHER RECLAIMED HISTORIES
}

\author{
Tom Phillips, Bath Spa University, t.phillips18@btinternet.com \\ 10.31902/fll.26.2019.3 \\ UDK 821.111.09
}

\begin{abstract}
The construction of counter-narratives which reclaim and rename history by challenging hegemonic discourse cannot simply be a question of replacing one metanarrative with another. Genuine counter-narratives also challenge the category of "the historical" itself, blurring its parameters and making value-claims for what is often regarded as historically insignificant or marginal. In this chapter, I examine works by three authors - George Orwell, Charles Olson and Georgi Gospodinov - who, despite the diversity of their outlook, output and circumstances, exhibit a shared interest in the significance of the seemingly insignificant and in its potentiality as a foundation for ethical challenges to the assumptions and definitions of hegemonic metanarratives. Winston Smith's diary in Orwell's 1984, the autobiographical anecdotes, obscure historical documents and local mythology included in Olson's Maximus Poems and the fragmentary texts of Gospodinov's Всички нашите тела are discussed in relation to Kierkegaard's notion of dignity in personal history, Lyotard's definition of postmodernism as an "incredulity towards metanarratives" and Auerbach's discussion of modernism in Mimesis, which also serves to illuminate continuities between the different "epochs" of the modernist/ post-modernist age as well as identifying a possible need to interrogate the way literary history itself is defined and narrated.
\end{abstract}

Keywords: history, significance, ethics, modernism, postmodernism, narrative, counternarrative

In this chapter I discuss the process of reclaiming and renaming history through the construction of counter-narratives around seemingly insignificant incidents and liminal situations. As well as introducing content into the category of 'the historical' which hegemonic, ideological metanarratives marginalises or excludes, such counter-narratives often reflect a scepticism towards the parameters, definition and indeed the very nature of the category itself. At the same time, attentiveness to the seemingly insignificant and marginal can be regarded as an ethical imperative and thus the construction of such counter-narratives can reflect ideological scepticism on the one hand and concern with the ethics of representation in hegemonic metanarratives on the other.

In order not to remain on a purely theoretical terrain, I examine three ostensibly unrelated works: the English novelist George Orwell's dystopia 1984, the American poet Charles Olson's Maximus Poems and the contemporary Bul- 
garian author Georgi Gospodinov's Всичките Наши Tела (All Our Bodies). Despite their evident differences, all three texts incorporate notions of reclaiming history through the reclamation of the personal and exhibit some of the various ways in which attentiveness to detail can reflect both ethical and ideological concerns. Although I discuss their work chronologically, I do not intend to imply that there is a linear progression from one to the next. Indeed, by relating their work to ethical and critical thinking which has variously been associated with modernism and/or postmodernism, I emphasise the continuities between then and implicitly critique the belief that postmodernism represents an abrupt and necessarily progressive 'break' from modernism.

I begin with Orwell's novel 1984 in which the totalitarian control of the Party encompasses and, indeed, depends on the control of the past. During his interrogation in the Ministry of Love in the final part of the novel, the protagonist Winston Smith is repeatedly reminded of this by his interrogator O'Brien.

"There is a Party slogan dealing with the control of the past," [O'Brien] said. "Repeat it, if you please."

"'Who controls the past controls the future; who controls the present controls the past,'” repeated Winston obediently. (Orwell, 248)

Until his arrest, of course, Winston has himself been complicit in this process. His job at the Ministry of Truth consists of destroying and replacing newspaper reports of historical events which no longer serve the ideological needs of the Party. He erases individuals who are no longer in favour, adjusts recorded state announcements so that past predictions about the chocolate ration tally with present changes to that ration and works all hours when Oceania switches allegiances from Eastasia to Eurasia and goes to war with the former, a switch which means that, according to the ideological logic of the Party and O'Brien: "Oceania has always been at war with Eastasia. Since the beginning of your life, since the beginning of the Party, since the beginning of history, the war has continued without a break, always the same war" (257).

Winston, in other words, is caught up in a system which continually reclaims and renames the historical narrative in the interests of the Party and its desire to maintain absolute power at all costs. It is no accident, therefore, that Winston's crime, the act of resistance which leads to his arrest and interrogation, begins with him opening a notebook and starting a diary, a personal history that counters the official version which he has to replicate and adjust at work. As Orwell puts it: "To mark the paper was the decisive act" (7).

Like many such personal histories, Winston's diary largely consists of seemingly inconsequential details. His first gesture of rebellion, in fact, is to describe a cinema audience's reaction to propaganda films [8], while one of the few entries that we're given at any length tells the story of Winston's en- 
counter with an elderly prostitute with whom he "went ahead and did it just the same" (69). To be sure, such apparently inconsequential episodes are interspersed with more explicit expressions of ideological rebellion - "Down with Big Brother" and so on - but I suspect that it's the seeming insignificance of Winston's other observations which gives his - and other - counter-hegemonic personal narratives their significance. Precisely what matters, in fact, is their insignificance and Orwell certainly sets up the conflict between personal diarymaking and the ideological fabrications of the Party's metanarrative as the central conflict of the novel: Winston's empirical observations of cinema crowds and prostitutes are set in opposition to the Party's ideological fiction or - to use today's terms - its post-truth and fake news.

In the novel, of course, Winston capitulates and there is no heroic triumph for the diary-keeper and would-be counter-hegemonic personal historian. The diary, like the paperweight from another era that Winston places in the room he rents for his trysts with Julia, is destroyed and Winston himself ends up conceding that, in some circumstances, it might be necessary for empirically observed facts to be replaced by ideological propositions: he admits that it might be expedient for two plus two to equal, not four, but five. Winston accepts the ideological metanarrative constructed by the Party, even though it apparently contradicts his own empirical observations and, indeed, itself:

He accepted everything. The past was alterable. The past never had been altered. Oceania was at war with Eastasia. Oceania had always been at war with Eastasia [...] How easy it was! Only surrender, and everything else followed [...] He hardly knew why he had ever rebelled! (278)

Instead of writing a diary, Winston now scrawls Party slogans and " $2+2=5$ " on a slate. And it is this capitulation which leads many people to consider the novel to be unremittingly bleak and pessimistic.

At the same time, however, the Party's response to the simple act of writing a diary seems wholly disproportionate. The regime has invested a great deal of effort in keeping Winston under surveillance:

He knew now that for seven years the Thought Police had watched him like a beetle under a magnifying glass. There was no physical act, no word spoken aloud, that they had not noticed, no train of thought they had not been able to infer. Even the speck of whitish dust on the cover of his diary they had carefully replaced. (276)

Similarly, in securing Winston's capitulation, O'Brien is forced to resort to torture. The techniques he deploys are brutal and excessive - "You know this is not necessary," observes Winston when, despite his assumption that he has already 
been utterly defeated, he is taken to Room 101 (284). In Oceania, the distinction Foucault made in Discipline and Punish: The Birth of the Prison between rigorous discipline, on the one hand, and spectacular punishment, on the other, breaks down: the Party has to deploy both sets of techniques in order to remain in power. Discipline is maintained by keeping Party members under continual observation (or at least in fear of continual observation) via their telescreens in a kind of giant panopticon, but this has apparently proved inadequate and the Party has to reinforce its disciplinary power with spectacular punishments reminiscent of the Spanish Inquisition, medieval witch trials or, in the form of the mask used to torture Winston in Room 101, "a common punishment in Imperial China" (286). For the Party to secure victory over its opponents and heretics (and we are reminded several times that Winston is far from being the only one subjected to torture in the Ministry of Love), it has to eschew logical or even ideological argument in favour of crude physical torture.

The excessiveness of the Party's mechanisms of control - their extensiveness, their brutality - seems to offer at least some grounds for hope. Winston himself, of course, believes - as he notes in his diary - that "If there is hope, it lies in the proles," (82) but I would also find it in the enormous lengths to which the Party has to go to extirpate Winston's humanity, in the number of other Party members being "processed" by the Ministry of Love and in the paranoia exhibited by a regime which cannot tolerate, not just a single dissenting voice, but every single dissenting thought - or, as O'Brien has it when he explains why Winston's subjugation is necessary: "You are a flaw in the pattern, Winston. You are a stain that must be wiped out" (255). Even a seemingly monolithic totalitarian regime which, O'Brien claims, makes all its predecessors, from the Spanish Inquisition through to Nazi Germany and the Soviet Union, look comparatively and self-defeatingly - liberal has its weaknesses and one of the ways in which to exploit them most effectively, it would seem, is to record and preserve personal counter-narratives as a means of reclaiming and renaming history. This is one thing which offers a genuine opportunity to subvert the Party's ideologically constructed metanarrative and the "collective solipsism" it generates (266).

That said, of course, the Party - and, by extension, all totalitarian and/or post-truth regimes - are probably right to be paranoid. In Lewis Carroll's Alice in Wonderland, after all, Alice overthrows the Queen of Hearts and her bloodthirsty regime with a single act of reclaiming and renaming - her famous assertion: "You're nothing but a pack of cards!"

At this the whole pack rose up into the air, and came flying down upon her: she gave a little scream, half of fright and half of anger, and tried to beat them off, and found herself lying on the bank, with her head in the lap of her sister, who was gently brushing away some dead leaves that had fluttered down from the trees upon her face. (Carroll, 141) 
The book ends with Alice reclaiming her own history and identity: she is not subject to the jurisdiction of the Queen's court or its circuitous and absurd narratives. Winston, of course, is denied this opportunity in 1984: he has no rabbit hole through which to escape. His story ends in tragedy (his capitulation and the prospect of his execution) while Alice's ends in farce (the metamorphosis of the Queen of Hearts and her court into a harmless pack of cards), but both seem to indicate the potential that personal histories have to counter the hegemonic official version.

Two philosophical propositions, one from the mid-19 ${ }^{\text {th }}$ century and one from towards the end of the $20^{\text {th }}$, delineate the horizons of Winston Smith's and, to some extent, Alice's - predicament. The first is from Søren Kierkegaard's Either/Or which opens with the assertion: "A human being's eternal dignity lies precisely in this, that he can gain a history" (Kierkegaard, 65). The second is from Jean-François Lyotard's The Postmodern Condition: A Report on Knowledge where he states: "Simplifying in the extreme, I define postmodern as incredulity towards metanarratives" (Lyotard, 392).

Read in the context of these two remarks, Winston's story becomes that of someone who, experiencing what Lyotard identifies as postmodern incredulity towards the Party's expedient fictions or metanarrative of power, attempts to "gain a history" - and therefore dignity - for himself by keeping a diary. When he is arrested, interrogated and tortured in the Ministry of Love, he loses his own history, his dignity and even his place in the Party's fictional metanarrative. As O'Brien tells him:

You will be lifted clean out from the stream of history. We shall turn you into gas and pour you into the stratosphere. Nothing will remain of you: not a name in a register, not a memory in a living brain. You will be annihilated in the past as well as in the future. You will never have existed. (Orwell, 254)

In Either/Or, however, Kierkegaard goes on to postulate what might constitute the kind of history which confers dignity on the individual - and this too might serve to illuminate the significance of Winston's diary. Kierkegaard distinguishes between what might be called "levels of witnessing" when he writes:

The person who lives ethically knows that what counts is what one sees in each situation, and the energy with which he considers it, and that the one who thus disciplines himself in the most insignificant life situations can experience more than the one who has been a witness to - indeed, been a participant in - the most noteworthy events. (Kierkegaard, 66) 
As I have already suggested, Winston's diary and his memories as recounted by the novel's narrator largely consist of "insignificant life situations" and it is possible to speculate that these both feed his incredulity towards the Party's metanarrative (they seem wholly at odds with the official version of history created by the Ministry of Truth) and constitute the subversive content of counternarrative. The scrupulous observation of insignificant events acquires an ethical value when it is deployed against the construction of a metanarrative consisting only of those events deemed "noteworthy" by those who, like the Party in 1984, have the power to confer or withdraw significance within a rigorously defined and closely controlled symbolic economy.

Here, then, I turn my attention to this relationship between insignificance, attentiveness and the reclaiming and renaming of history and to a poet who ostensibly seems to be engaged in a very different kind of project - that is, the creation of an epic, a form more usually associated with "noteworthy events" than with "insignificant life situations."

Generally regarded as the key figure amongst the so-called Black Mountain poets who began publishing their work in the USA in the mid-20 ${ }^{\text {th }}$ century, Charles Olson is best-known for his sprawling, heterogenous project The Maximus Poems. On the face of it, it's a project which resembles Ezra Pound's The Cantos - a vast, open-ended, unfinished and unfinishable sequence which seeks to present America with its equivalent of The Odyssey or The Iliad. Olson certainly strikes a Poundian note in the opening poem of the sequence, "I, Maximus of Gloucester, to You":

Off-shore, by islands hidden in the blood jewels \& miracles, I, Maximus, a metal hot from boiling water, tell you what is a lance, who obeys the figures of the present dance (Olson, 5)

At this point, in the opening forays of the sequence, the persona of Maximus resembles the didactic, bombastic and self-aggrandising personae whose voices sound throughout Pound's Cantos. Maximus, however, proves to be somewhat less sure of himself and the sequence becomes noticeably less sonorous as it develops. In his introduction to the Penguin Book of American Verse, Geoffrey Moore compares the two poets, arguing that Olson is an "imitation" while Pound is the "real" thing and that the former "did not have Pound's power or [William Carlos] Williams's human sympathy - or the talent of either of them, so that the result too often reads like pastiche" (Moore, 37-39). This unfavourable and rather harsh judgement arises, I suspect, from what might be called Olson's retreat from the epic scope which Pound attempts to sustain 
as he sweeps up vast swathes of history from the early USA, Renaissance Italy, Confucian China, medieval Provence and so on in a bravura display of centripetal force. In contrast, Olson increasingly comes to find his "jewels \& miracles" closer to home and if he discovers parallels with other histories - his use of the term polis, for example, encourages a comparison between American and Ancient Greek notions of democracy - his principal activity is closer to archaeology, a delving down into a specific place (the town of Gloucester on the Massachusetts coast), the random and trivial details which remain of its history and the anecdotal personal narratives which are attached to it. The poem "Maximus to Gloucester, Letter 27 [withheld]," for example, begins with what we can probably assume is an autobiographical reminiscence:

I come back to the geography of it, the land falling off to the left where my father shot his scabby golf and the rest of us played baseball into the summer darkness until no flies could be seen and we came home to our various piazzas where the women buzzed

A few lines later, this seemingly inconsequential episode from a personal history is supplemented by another, potentially more consequential one which trails off in an unfinished sentence:

I was so young my first memory

is of a tent spread to feed lobsters

to Rexall conventioneers, and my father, a man for kicks, came out of the tent roaring with a bread-knife in his teeth to take care of the druggist they'd told him had made a pass at my mother, she laughing, so sure, as round as her face, Hines pink and apple, under one of those frame hats women then

A few lines later again, Olson moves on from these autobiographical fragments and makes two statements which are probably the closest he gets to articulating the nature of the Maximus project as he sees it. The first reads: "There is no strict personal order/for my inheritance." The second: "An American is a complex of occasions." Both of these statements, it seems to me, indicate that 
Olson at least has an eye on reclaiming and renaming history by unearthing his "inheritance" (even if he may never find a "strict personal order" for it) and delving into "the complex of occasions" which feeds into and constitutes an intensely singular identity within the context of the polis or the communal - that is, as he puts it a few lines later, "all that I no longer am/yet am" (184-5). Here, in this paradox, we might hear an echo of Kierkegaard's thought about the relationship between history and dignity: despite the seeming rupture between present and past, "now" and "no longer", articulating "all that I no longer am" is one way to endow the assertion "I am" - within and in relation to the polis with meaning and value.

Olson's sequence, in other words, is neither purely autobiographical nor epically historical. As it develops, in fact, the scrutiny of "insignificant life situations" becomes central and offers opportunities to reread and reassess the official version of US history through the prism of Olson's archaeological explorations of both the town of Gloucester and himself. This at least seems to be what's behind the inclusion of documentary sections such as the opening of "Maximus, in Gloucester Sunday, LXV":

Osmund Dutch, and John Gallop, mariners, their wages

asked that they be paid to the Dorchester

Co., July, 1632. Thus Reverend John White writing

to John Winthrop at Boston locates

Dutch and Gallop as on this coast or ferrying others across the Atlantic at a probable date earlier than 1630 (449)

Ostensibly, this resembles some of the documentary elements Pound includes in The Cantos (most notably The Adams Cantos LXI-LXXI), except that Olson's focus isn't on historical figures like John Adams, but on "mariners," "probable" dates, the unspecified "ferrying" of "others" (settlers or slaves, perhaps) across the Atlantic. His history emerges from "the geography of it," from the ground up. As it does too in the semi-mythologised material based around Dogtown, the city of Gloucester's earthier counterpart and alter-ego, where characters like the bull-baiting Merry lurk in the shadows of mainstream history:

Drunk

to cover his shame

blushing Merry

in the bar

walking up 
To Dogtown to try
his strength,
the baby bull
now full grown
waiting,
not even knowing
death
was in his power over
this man who lay
in the Sunday morning sun (174)

What Olson is doing, then, seems very different from what Pound aspired to in his more self-consciously epic sequence. Where Pound attempts to marshal history into patterns which elucidate its epochal "rhymes" and which make it cohere according to a template of his own devising, Olson deploys similar techniques (allusion, citation, documentation, myth, anecdote), but along a trajectory which leads away from the construction of an all-encompassing metanarrative. Likewise, where Pound effectively leaves the category of "the historical" untouched, Olson's gaze is directed towards its margins and its marginalia, not necessarily redefining the concept of history itself, but at least fretting at its boundaries and, in so doing, exhibiting the kind of incredulity in metanarratives which Lyotard identifies with the postmodern. The difference between the two poets, in other words, is not one which can be conflated into the simplistic distinction between the "real" and the "imitation" which Geoffrey Moore employs. The Maximus Poems are not an "imitation" of The Cantos because, unlike Pound's epic, they are not manifestations of a high modernist aesthetic; they are a wholly different enterprise and that difference hinges on the distinction which Kierkegaard makes between "insignificant life situations" and "noteworthy events" and on the incredulity towards metanarratives which Lyotard identifies. Given their self-evident ideological differences, it's also tempting to see Pound's Cantos as being closer to the manufactured history produced by the Ministry of Truth and Olson's Maximus Poems as being closer to Winston Smith's diary.

As it happens, this analogy to 1984 may not be so far-fetched. As is wellknown, Pound aligned himself with Mussolini's totalitarian regime until it became expedient for him to renounce it while, during the Second World War, Olson was employed in a role which sounds uncannily similar to that of Winston Smith. Although hired by the Democratic Party, Olson's place of work was the US Office of War Information - an organisation which, despite its Orwellian name, was set up to protect ethnic minorities from war-inspired hostility - where he 
wrote press releases which were tampered with in the name of promoting a particular ideology. Unlike Winston, Olson was able to resign when he felt that this tampering, this promulgation of "fake news", had gone too far, but he continued his solo combat with the American political system, with individual politicians and with "the political ego" itself, both whilst he was at Black Mountain College in North Carolina and after he took up residence in Gloucester where he wrote the majority of The Maximus Poems. As Craig Stormont points out in his essay "Charles Olson: The Political Ego Condemned":

Olson's indictment of Gloucester's political leaders, whom he unequivocally accuses of marring the process [...] has been largely misinterpreted or ignored by critics in their analysis of Olson's work. Olson focuses on Gloucester because it is both rich in history and where he was located while composing many of The Maximus Poems, but the political activities that were occurring there signify the ego-related flaws that remain systemic in the current American political scheme, and they are treated in his epic. (Stormont)

Here, though, I am starting to reclaim and rename history myself. Literary history is also a field of contestation in which traditions and trends, individual writers and individual works are open to continual reappraisal, often in the name of reclaiming the overlooked, the marginal and the unanthologised. Olson, of course, is not an entirely marginal figure. Even the reluctant Geoffrey Moore allows "I, Maximus of Gloucester, to You" into his Penguin anthology and, somewhat paradoxically, accords more space in his introduction to Olson and the Black Mountain poet's theory of "projective verse" than he does to many other American writers whom he considers to be more "authentic" (Moore, 3739). It is true, however, that - as Stormont argues in relation to his political engagement - Olson is frequently misrepresented as a neo-Poundian or late high modernist, an aesthetic theorist rather than a creative practitioner or, as Moore has it and worst of all, a mere pasticheur. All too frequently, these misrepresentations enable his work to be categorised as "difficult" and "obscure" and therefore safely pushed out towards the margins. Critics, anthology editors and others involved in the construction of literary history have allotted Olson and his fellow Black Mountain Poets (Ed Dorn, Denise Levertov, Robert Creeley, Robert Duncan et al) a position of some significance in the post-war American poetic canon, but it tends to be other groupings which have conventionally come to be accorded centrality: the Confessional poets (Robert Lowell, Sylvia Plath, John Berryman...); the Beats (Allen Ginsberg, Lawrence Ferlinghetti, Gregory Corso...) and the New York School (John Ashbery, Frank O'Hara, Kenneth Koch...).

This at least is how it seemed from the UK where, until the publication of Ed Dorn's Collected Poems in 2012 by Manchester's Carcanet Press, substantive 
selections of work by any of the Black Mountain Poets were hard to come by. Moreover, UK poets influenced by, associated with or affiliated to this particular strand of post-war American poetry - Basil Bunting, Jeremy Prynne, Roy Fisher, Andrew Crozier and R.F. Langley amongst them - were themselves categorised as "difficult", "experimental" and "avant garde" and similarly marginalised. As it happens, many of these poets who began publishing in the 1950s and 1960s (and considerably earlier in some cases) are now being somewhat tardily rehabilitated and written back into UK literary history - thanks largely to publishers like Bloodaxe and Carcanet bringing out substantial collections of their work. These rehabilitations or reclamations are only necessary, however, because for a long time UK poetry was curated by writers and critics who were - often openly - hostile to the tendencies represented by Bunting, Prynne, Fisher, Crozier and Langley. The Penguin Book of Contemporary British Poetry, edited by Andrew Motion and Blake Morrison and published in 1982, for example, offers a highly prescriptive definition of what constituted British poetry in the 1970s and early 80s, conspicuously overlooking those working outside what they evidently considered the boundaries of the mainstream. To be sure, the anthology incorporates many poets whose work more than justifies their inclusion - Seamus Heaney, Derek Mahon, Geoffrey Hill and so on - but it's also true that its rollcall includes others whose work might be best described by Hill's telling phrase from "The Mystery of the Charity of Charles Peguy" as "brave, mediocre work." The big claims made by the anthology's title - and indeed its introduction were belied by its contents and, as one critic recently commented in an email to me, "the bloody consequences of that anthology are still only now being recognised." In short, this and several other supposedly era- or at least generationdefining anthologies have overlooked an entire strand of post-war literature and, in so doing, have misleadingly represented contemporary British poetry as being rather conservative, obsessed with clever metaphors and, indeed, somewhat parochial, isolated from both American and European late modernism and postmodernism and indeed from international poetry in general.

In some cases, of course, the poets concerned contributed to their own marginalisation, not because they deliberately wrote "difficult" poetry, but because they actively avoided the conventional mechanisms for publishing and disseminating their work - usually on the grounds that using such mechanisms would make them complicit in a profit-oriented economic system and a political superstructure to which they were opposed. For them, in short, it was no good complaining about capitalism and its monetization of value if you then went out and tried to get yourself a three-book deal with one of the big profit-oriented publishing houses. Their "incredulity toward the metanarrative," which Lyotard identifies as a defining characteristic of the postmodern (but which I would identify with many writers usually placed within the horizons of modernism as 
well), extends beyond the content of the narrative itself to the definition of "the literary" and "the historical" and to the economic means which feed into or influence the production of these categories themselves. In short, what I detect in the work and actions of these poets on both sides of the Atlantic is a desire not to populate the field of "the historical," "the literary" and "the literary historical" with alternative facts, events, publications, names, but a belief that the discursive templates, the contours of these fields themselves need to be redefined, renamed and thereby reclaimed if we are ever to encounter culture and history as dynamic and negotiable symbolic economies rather than as static templated simulacra.

With this digression, then, I hope to illustrate that reclaiming and renaming history is not simply a case of inserting different content into a ready-made model. It is not simply about re-ordering what is already present, already deemed significant, or readdressing Kierkegaard's "noteworthy events" - which is what, to a large extent, writers like Pound tend to do. It is not simply about bearing witness to history from a different perspective or ideological position. It is also about redefining "the historical" itself - as I believe Olson and the other poets I've mentioned in connection with him do - through the scrupulous observation of apparently "insignificant life situations" in the name of discovering their significance and of according them a value which might otherwise remain unacknowledged. As William Carlos Williams has it in his most well-known short poem:

so much depends

upon

a red wheel

barrow

glazed with rain

water

beside the white

chickens. (Williams, 264)

If this is most usually understood an an aesthetic proposition, the quintessential poetic expression of Williams' mantra "no ideas but in things," it might also indicate the kind of recognition and the kind of questions that the process of reclaiming and renaming history entails: the recognition of the significance in the apparently trivial and consequent questions about the nature of the content of the "so much" which might depend on it.

For Erich Auerbach, this focus on the mundane is a characteristic of modernism. In Mimesis, his monumental study of narrative from Homer to Woolf, Joyce and Proust, he observes of the latter: 
now many writers present minor happenings, which are insignificant as exterior factors in a person's destiny, for their own sake or rather as points of departure for the development of motifs, for a penetration which opens up new perspectives into a milieu or a consciousness of the given historical setting. They have discarded presenting the story of their characters with any claim to exterior completeness, in chronological order, and with the emphasis on important exterior turning points of destiny. James Joyce's tremendous novel [Ulysses] - an encyclopaedic work, a mirror of Dublin, of Ireland, a mirror too of Europe and its millennia has for its frame the externally insignificant course of a day in the lives of a schoolteacher and an advertising broker. (Auerbach, 547)

As it happens, of course, Joyce reclaimed and renamed the history of 16 June, 1904 in ways that he couldn't possibly have imagined, with the anniversary of the original Bloomsday now celebrated around the world and with the fictional events of his novel now coming to have a more firmly established imaginary "reality" than the given historical setting of the actual 16 June, 1904. Here again, though, we can see how, beyond the aesthetic shift which Auerbach identifies, literature's focus on "minor happenings" might be understood in terms of - and might contribute to - an ongoing reappraisal of "the historical" and, indeed, "the historic". Like William Carlos Williams' "The Red Wheelbarrow" and Olson's Maximus Poems, Joyce's Ulysses, Woolf's Mrs Dalloway and Proust's A La Recherche De Temps Perdu can also be read as texts which question the historical metanarrative, not by rearranging "noteworthy events," but by scrupulously observing "insignificant life situations."

Here, then, I turn my attention to the contemporary Bulgarian author, Georgi Gospodinov, whose work is frequently referred to as postmodernist, and yet whose interest in the insignificant and the fragmentary is similar in kind to that of the writers identified as modernist by Auerbach. Gospodinov's Ecmeствен роман or Natural Novel from 1999, for example, focuses almost entirely on "minor happenings." The framing narrative - if it can be called that - concerns a seemingly archetypal and personally, if not necessarily historically significant situation: a character called Georgi Gospodinov is being divorced by his wife Emma who is pregnant by another man. This Georgi Gospodinov - and there are several who appear in the text, none of whom, it's probably safe to assume, is the empirically existing Georgi Gospodinov who wrote the novel seems relatively unmoved by this and there is certainly no attempt to turn this story into a grand and tragic narrative. Much of the novel, in fact, consists of apparently inconsequential anecdotes, pub conversations, quotations from other novels, pseudo-philosophical riffs on various subjects (occasionally scatological), parables and so on. As the American novelist Garth Greenwell observes in 
an article in The New Yorker: "Gospodinov rejects grand narratives altogether, offering in their place a polyphonic microchronicle of moments" (Greenwell).

Arguably, Gospodinov's novel takes us beyond even Kierkegaard's "insignificant life situations" and Auerbach's "externally insignificant course of a day," and many of the moments recounted in it appear to be beyond insignificance. They are spectacularly marginal, as if the entire book has been constructed from outtakes from the kind of naturalist and modernist autobiographical and biographical novels whose beginnings the narrator - or one of the narrators tries out as possible openings to his own narrative. Even the most naturalistic - as opposed to natural - of novelists have filtered such minor happenings out. That one of the lengthiest chapters in the novel is evidently recounted by a fly exemplifies Gospodinov's interest in the hyper-marginal and his exploration of its possibilities as a foundation for a genuinely natural aesthetic and counternarrative to set against the metanarratives which currently populate the categories of "the literary" and, by implication, "the historical."

This interest and disposition towards metanarrative and, indeed, narrative itself is made equally explicit in his most recent publication, 2018's Всичкu нauume тела/All our bodies, a collection of prose fragments, many of which are no more than a few sentences long. Again, these are provisional moments, shards of experience, which we are evidently not expected to thread together around any kind of overarching narrative. In many ways, in fact, the individual pieces gathered into the book defy any kind of categorisation: some resemble prose-poems, some resemble flash fiction, some resemble the routines of William S. Burroughs. And yet, as Gospodinov himself points out in the longest piece in the book, the end-note entitled "On brevity and this book - briefly," there is nothing new about this. Literary tradition incorporates all manner of fragments and, he says:

Completely chaotically, as in a Borgesian encyclopaedia, we might list ancient stone inscriptions, Buddhist koans, the 'characters' of Theophrastus, Biblical parables, apocrypha, the annotations of anonymous scribes on the fly-leaves of sacred books. (Gospodinov, 138)

For Gospodinov, too, the fragment offers a challenge to the prevailing market-driven literary hierarchy:

There is a fixed hierarchy in contemporary literature, according to which the novel is above everything else [...] What's left for very short stories, fragments and sentences? They don't become bestsellers and blockbusters, they're too short. Their ant-like bodies can't compare with the elephantine novel. But again the subversive quality of brief stories, their 
ability to escape from under the novel's yoke appeals to me. And it particularly appeals to me now, in times of heavyweight epic. (Gospodinov, 137)

This last sentence can also be read from a broader perspective as a reference, not only to blockbuster novels, but also to other forms of heavyweight discourse in the media, political rhetoric, contemporary history and so on.

Again, then, it is a book which privileges seemingly insignificant, marginalised and neglected personal histories and offers an alternative to prevailing metanarratives and categorisation of the historical in the name of challenging their predominance. Here, for example, he refers directly to the histories which have been deemed "impossible" and yet could be included within the horizon of the historical:

\section{I collect impossible histories}

Such as

The history of clouds in the $12^{\text {th }}$ century

The history of the desire to be elsewhere

The history of flies born in 1968 (and dead the same year)

The history of sorrow at $6 \mathrm{pm}$

The history of impossible histories

My collection, of course, is empty. And precisely because of that, possible. (Gospodinov, 23)

This short piece draws attention to the question of how and why value and meaning are accorded to some histories and not to others and in 'One and the same life', also collected here, Gospodinov offers grounds for considering all histories, no matter how seemingly insignificant, with the kind of scrupulous attention which Kierkegaard refers to:

I suspect that, for the vine fly, which lives for 24 hours and for the Galapagos tortoise, hauling its shell around for more than 100 years, the experience of time is one and the same. Everything the tortoise down over a century happens to a fly in a day - birth, maturity, procreation, old-age, death. One equally rich and detailed life. [Gospodinov, 94]

Although this isn't an allegory or fable per se, it can, of course, be read allegorically and, indeed, invites us to do so. We can map this observation, this suspicion, onto the human world and regard it as both a radically egalitarian and 
radically generous understanding, the implication being - in the context of Gospodinov's remarks about narrative cited above - that, if we all lead "One equally rich and detailed life", then all our histories, all our narratives have equivalent meaning and value.

Like Orwell and Olson, then, Gospodinov combines a Kierkegaardian ethic with Lyotardian scepticism: the scrupulous observation of "insignificant life situations" coexists with a distrust in the construction of narratives which seek to present a seamless and ideologically inflected - or in many cases ideologically controlled - interpretation of the world. Significantly, of course, Gospodinov although born in Bulgaria in 1968 - is not necessarily writing about the country's socialist period in which he grew up: the constructed narratives to which his "microchronicles" offer both an alternative and a challenge might be those of actually existing socialism, but they also might be those of Bulgaria's difficult post1989 transition period, of neo-liberalism more broadly or simply those which a market-driven literary industry has chosen to mark out as potential blockbusters and bestsellers. Orwell's target was more specific - the totalitarianism he observed in Nazi Germany, fascist Italy, Soviet Russia and, indeed, wartime Britain - and Olson's poetry might also be fruitfully read in the context of McCarthyite America, but all three exhibit a concern with the essence and politics of narrative which, in their own different ways, might be set against Francis Fukuyama's assertion that history ended in 1989 and that we have now fully entered a phase of post-historical neo-liberalism. Orwell and Olson, of course, couldn't have read Fukuyama's diagnosis, but I suspect that they would have identified as another example of an ideologically constructed metanarrative while Gospodinov's fragments appear to represent a shoring-up against the blithe assumptions of neo-liberalism which plays with notions of postmodernism, but which is actually founded in an ethics stretching back through Lyotard to modernism and phenomenology, Kierkegaard and beyond. As Gospodinov puts it, the role of counter-narrative is to chronicle "One equally rich and detailed life" (94).

\section{Works Cited:}

Auerbach, Erich. Mimesis. Princeton: Princeton University Press, 1968. Print.

Carroll, Lewis. Alice in Wonderland. Ware: Wordsworth, 1992. Print.

Foucault, Michel. Discipline and Punish: The Birth of the Prison. New York:

Pantheon Books, 1977. Print

Fukuyama, Francis. The End of History and the Last Man. New York: Free Press, 1992.

Gospodinov, Georgi. Всички нашите тела. Plovdiv: Janet 45, 2018. Print.

English translations by Tom Phillips (unpublished). 
Greenwell, Garth. "The Bulgarian sadness of Georgi Gospodinov". New Yorker, 2018. Web. 25 May 2018. https://www.newyorker.com/books/pageturner/the-bulgarian-sadness-of-georgi-gospodinov

Kierkegaard, Søren. "Either/Or." Continental Philosophy: An Anthology. Ed. William McNeill and Karen S. Feldman. Oxford: Blackwell, 1998. Print.

Lyotard, Jean-François. "The Postmodern Condition: A Report on Knowledge."

Continental Philosophy: An Anthology. Ed. William McNeill and Karen S. Feldman. Oxford: Blackwell, 1998. Print.

Moore, Geoffrey (ed.). The Penguin Book of American Verse. Harmondsworth: Penguin, revised edition 1983. Print.

Olson, Charles. The Maximus Poems. Berkeley: University of California Press, 1983. Print.

Orwell, George. 1984. New York: Signet Classics, 1950. Print.

Stormont, Craig. "Charles Olson: The Political Ego Condemned." Flashpoint, 2018. Web. 16 May 2018. http://www.flashpointmag.com/cstorm.htm Williams, William Carlos. 'The Red Wheelbarrow'. The Penguin Book of American Verse. Ed. Geoffrey Moore. Harmondsworth: Penguin, revised edition 1983. Print.

\section{ЗНАЧИМОТО В НЕЗНАЧИТЕЛНОТО: ДНЕВНИКЪТ НА УИНСТЪН СМИТ И ДРУГИ ПРЕОСМИСЛЕНИ ИСТОРИИ}

Конструирането на контра-наративи, които преосмислят и пренаписват историята, противопоставяйки се на доминиращия дискурс, не може просто да бъде въпрос на замяна на един метанаратив с друг. Истинските контра-наративи оспорват дори и самата категория „историчност“, като размиват нейните граници и откриват стойностното в това, което често се счита за исторически незначително или маргинално. В тази глава разглеждам творби на трима автори - Джордж Оруел, Чарлз Олсън и Георги Господинов - които, въпреки разнообразието на техните възгледи, произведения и условията, в които работят, проявяват общ интерес към значимостта на привидно незначимото и способността му да води до етично преразглеждане на възгледите и дефинициите на общоприетите метанаративи. Дневникът на Уинстън Смит в романа „1984” от Оруел, автобиографичните сюжети, слабо известните исторически документи и местната митология, включени в стиховете от Олсъновия „Максимус“, и фрагментарните текстове на „Всички наши тела» от Господинов се разглеждат във връзка с представата на Киркегор за достойнството в личната история, дефиницията на Лиотар за постмодернизма като „недоверие към метанаративите” и дискусията на Ауербах за модернизма в „Мимезис”. Това също така спомага да се осветли 
приемствеността между различните „епохи” на модернистичния /постмодернистичния период, както и да се установи дали и доколко е необходимо да се преразгледа начинът, по който се определя и се разказва самата литературна история.

Ключови думи: история, значение, етика, модернизъм, постмодернизъм, наратив, контра-наратив. 